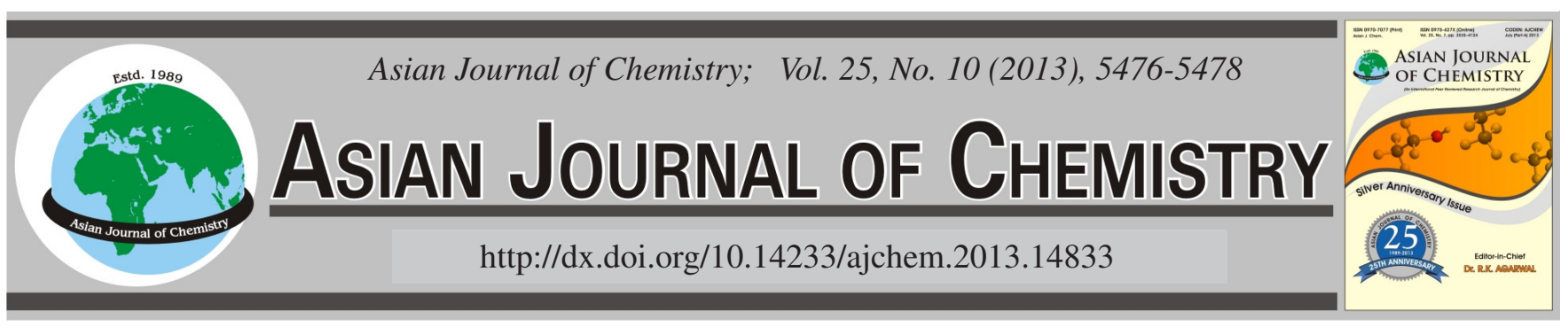

\title{
Bioaccumulation of Copper and Zinc in Freshwater Crayfish (Astacus leptodactylus) Fed with Zebra Mussels (Dreissena polymorpha) Collected from Keban Dam Lake, Turkey
}

\author{
Onder Aksu ${ }^{1, *}$, Azime Kucukgul Gulec ${ }^{1}$, Veysel Demir $^{2}$, Durali Danabas ${ }^{1}$, \\ Numan Yildirim ${ }^{2}$, Mehtap OzCeliK ${ }^{3}$, ERKan Can $^{1}$ and Mehmet Kocabas ${ }^{4}$
}

${ }^{1}$ Fisheries Faculty, Tunceli University, 62000 Tunceli, Turkey

${ }^{2}$ Department of Environmental Engineering, Faculty of Engineering, Tunceli University, Tunceli, Turkey

${ }^{3}$ Vocational School of Health Sciences, Bingol University, Bingol, Turkey

${ }^{4}$ Department of Wildlife Ecology, Karadeniz Technical University, Trabzon, Turkey

*Corresponding author: Fax: +90 428 2131861; Tel: +90 428 2131794-1234; E-mail: onderaksu@ tunceli.edu.tr

(Received: 21 November 2012;

Accepted: 13 April 2013)

AJC-13234

\begin{abstract}
This study is aimed to determine the bioaccumulation of copper and zinc in hemolymph of freshwater crayfish (Astacus leptodactylus) fed with zebra mussel (Dreissena polymorpha) collected from Keban Dam Lake. This is the first study on bioaccumulation of Cu and $\mathrm{Zn}$ in hemolymph of males and females of A. leptodactylus. The average concentrations of $\mathrm{Cu}$ and $\mathrm{Zn}$ in the hemolymph samples were found out as 0.54 and $35.07 \mathrm{ppm}$ respectively for male and 0.42 and $15.59 \mathrm{ppm}$ respectively for female control freshwater crayfish. The levels of $\mathrm{Zn}$ in the hemolymph of both male and female ones among control and diet groups were statistically significant $(\mathrm{P}<0.05)$. The $\mathrm{Cu}$ levels among control and diet groups in female ones were statistically significant $(\mathrm{P}<0.05)$ but not in the male ones $(\mathrm{P}>0.05)$. The results of current study revealed that feed treatment with boiling was not effective at the levels of metal bioaccumulation in hemolymph. It was observed that this metal bioaccumulation is more related with sex differences.
\end{abstract}

Key Words: Astacus leptodactylus, Metals, Dreissena polymorpha, Bioaccumulation.

\section{INTRODUCTION}

The use of indicator species in aquatic ecosystems seems to be a suitable way of monitoring water quality due to the ability of some aquatic animals to accumulate metallic ions either directly from the surrounding water or indirectly through food sources ${ }^{1}$. Since crayfish is solitary bottom dwellers which keep much of their bodies in contact with surrounding objects and tend to accumulate metals in their tissues, they can be used to monitor the aquatic environments for trace metal pollution $^{2,3}$.

Biologically essential trace metals such as zinc and copper are taken up by aquatic invertebrates both from food or/and water and they are also known as toxicants ${ }^{4,5}$. Copper and zinc are essential trace elements for physiological functions of enzymes and beneficial to the health of all living ${ }^{6}$. Copper and zinc are also required for biological activities for some enzymes like SOD. In humans, copper deficiency may cause total activity loss and several sicknesses ${ }^{7,8}$. In freshwater decapods, copper is a regulated metal due to biochemical role of this metal in the production of the respiratory haemocyanin $^{9,10}$. Decapod crustaceans typically maintain the tissue and body concentrations of the essential metal zinc at approximately constant levels upon exposure to a wide range of ambient dissolved $\mathrm{Zn}$ concentrations ${ }^{10,11}$.

Several studies have been performed to investigate $\mathrm{Zn}$ and $\mathrm{Cu}$ accumulation in body tissues and organs of different species of crayfish ${ }^{4,12}$. Zinc and copper were bound by blood proteins metallothioneins and most of copper in decapods crustaceans was found in their blood and hepatopancreas 9 .

Crayfish utilize zebra mussels as a food source and may accumulate trace metals. Therefore, monitoring the possible heavy metal presence in crayfish edible tissues is important since crayfish can be part of the human $\operatorname{diet}^{13}$.

The objective of this study is to determine the bioaccumulation of copper and zinc in hemolymph of freshwater crayfish (Astacus leptodactylus) fed with zebra mussel (Dreissena polymorpha) collected from Keban Dam Lake.

\section{EXPERIMENTAL}

Freshwater crayfish (A. leptodactylus) from reference site and zebra mussels (D. polymorpha) from polluted site were collected at Keban Dam Lake in February 2011 (Fig. 1). Some properties and location of sampling sites were summarized in 
Table-1. Carapace length and total weight of the crayfish were measured using a digital caliper in the laboratory. Crayfish were held in plastic tanks containing $40 \mathrm{~L}$ of water. The basic water parameters during the experiment were maintained at range of $10-15 \mathrm{mg} / \mathrm{L}$ dissolved oxygen and $14-16^{\circ} \mathrm{C}$ temperature.

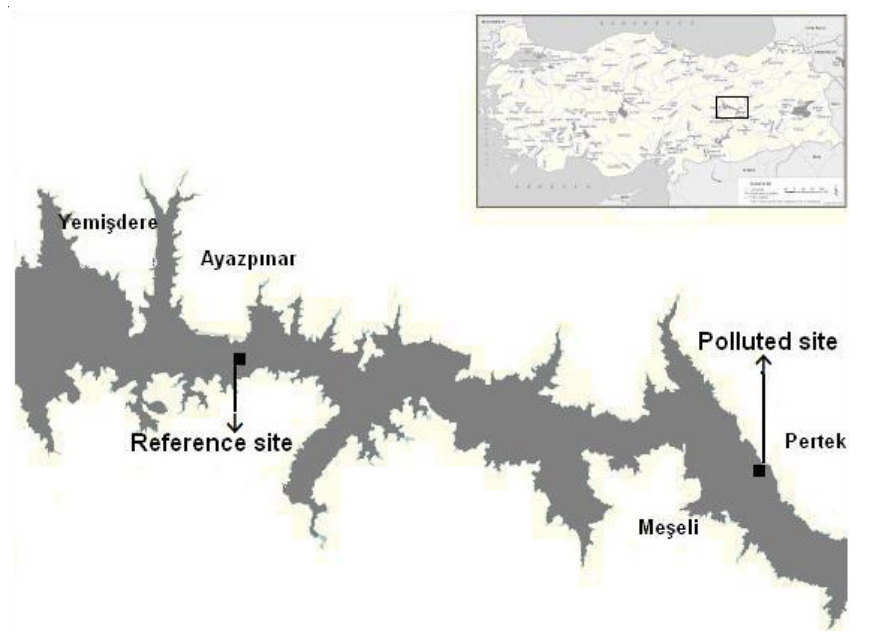

Fig. 1. Map of sampling sites on Keban Dam Lake

Total 30 adult crayfish with the average size of $46 \mathrm{~mm}$ carapace length and zebra mussels with the average size of 14 $\mathrm{mm}$ total length were used in the experiments. Crayfish were separated into three groups (10 individuals for each group). The content of trace metals in the hemolymph of the first group crayfish (control group) was measured after collected from reference site on Keban Dam Lake. The first experimental group of the crayfish (diet 1) was fed with boiled mussel while those in the second group (diet 2) were fed with not boiled mussel. Each diet was offered ad libitum to the crayfish for a period of 21 days.

TABLE-1

PROPERTIES AND LOCATIONS OF SAMPLING SITES

\begin{tabular}{|c|c|c|}
\hline Sampling sites & Locations & Properties \\
\hline References site & $\begin{array}{l}\text { Ayazpinar province of } \\
\text { Tunceli } 38^{\circ} 50^{\prime} 24.27 " \mathrm{~N} \text {, } \\
39^{\circ} 17^{\prime} 33.69^{\prime \prime} \mathrm{E}\end{array}$ & $\begin{array}{l}\text { Rural area, There is no } \\
\text { municipal or industrial } \\
\text { discharge point }\end{array}$ \\
\hline Polluted site & $\begin{array}{l}\text { Pertek province of } \\
\text { Tunceli } 38^{\circ} 53^{\prime} 20.33^{\prime \prime} \mathrm{N} \text {, } \\
39^{\circ} 02^{\prime} 34.10^{\prime \prime} \mathrm{E}\end{array}$ & $\begin{array}{l}\text { Near the urban area } \\
\text { and this site has a lot } \\
\text { of municipal waste } \\
\text { discharging points }\end{array}$ \\
\hline
\end{tabular}

Sampling of hemolymph: Samples of hemolymph were extracted with puncturing the arthrodial membrane at the base of the most posterior walking leg with a disposable $1 \mathrm{~mL}$ syringe and a $24 \times 0.5 \mathrm{~mm}$ sterile needle. The hemolymph was analyzed for total $\mathrm{Zn}$ and $\mathrm{Cu}$ concentrations according to AOAC 999.10 method, Atomic AbsorptionSpectrophotometry (Perkin Elmer AA- 800) after microwave digestion ${ }^{14}$.

Statistical analyses: Data were analyzed using the SPSS computer program (SPSS 15.0 for Windows, Chicago, Illinois, USA). Results are expressed as mean \pm standard error (mean $\pm \mathrm{Se}$ ). Metal content of hemolymph was compared among the control and experimental groups using one-way ANOVA and Duncan's multiple range test. Independent t-test was also used to analyze for association between metal content and sex differences.

\section{RESULTS AND DISCUSSION}

Bioaccumulations of $\mathrm{Cu}$ and $\mathrm{Zn}$ in hemolymph in fresh water crayfish, A. leptodactylus were given in Table-2. The average concentrations of $\mathrm{Cu}$ and $\mathrm{Zn}$ in the crayfish hemolymph samples were found as 0.54 and $35.07 \mathrm{ppm}$, respectively for male and 0.42 and $15.59 \mathrm{ppm}$, respectively for female control freshwater crayfish.

\begin{tabular}{|c|c|c|c|c|}
\hline \multicolumn{5}{|c|}{$\begin{array}{c}\text { TABLE-2 } \\
\text { MEANS } \pm \text { SE, Cu AND Zn CONCENTRATIONS (ppm) } \\
\text { IN HEMOLYMPH OF FRESHWATER CRAYFISH, } \\
\text { FED WITH DIFFERENT DIETS }\end{array}$} \\
\hline \multicolumn{2}{|l|}{ Parameters } & \multicolumn{2}{|c|}{ Experimental groups } & \multirow[b]{2}{*}{ D2 } \\
\hline Metals & Sex & Control & D1 & \\
\hline \multirow{4}{*}{$\mathrm{Zn}$} & Male & $0.54 \pm 0.04^{b}$ & $0.31 \pm 0.06^{\mathrm{a}}$ & $0.36 \pm 0.04^{\mathrm{a}^{*}}$ \\
\hline & Female & $0.42 \pm 0.14^{\mathrm{a}}$ & $0.50 \pm 0.09^{\mathrm{ab}}$ & $0.92 \pm 0.13^{\mathrm{b}}$ \\
\hline & $\begin{array}{l}\text { Mean } \\
\text { levels }\end{array}$ & $0.48 \pm 0.07^{\mathrm{a}}$ & $0.40 \pm 0.06^{\mathrm{a}}$ & $0.64 \pm 0.09^{\mathrm{a}}$ \\
\hline & $P$ values & 0.424 & 0.110 & 0.002 \\
\hline \multirow{4}{*}{$\mathrm{Cu}$} & Male & $35.07 \pm 2.64^{a^{*}}$ & $25.30 \pm 3.47^{\mathrm{a}}$ & $30.64 \pm 3.67^{a}$ \\
\hline & Female & $15.59 \pm 3.25^{\mathrm{a}}$ & $29.30 \pm 1.11^{b}$ & $23.60 \pm 1.63^{b}$ \\
\hline & $\begin{array}{l}\text { Mean } \\
\text { levels }\end{array}$ & $25.33 \pm 3.80^{\mathrm{a}}$ & $27.30 \pm 1.84^{\mathrm{a}}$ & $27.12 \pm 2.11^{\mathrm{a}}$ \\
\hline & $P$ values & 0.002 & 0.305 & 0.097 \\
\hline
\end{tabular}

Different letters in the same line indicate significant differences among means of control and diet groups according to Duncan's multiple range test $(\mathrm{P} \leq 0.05)$. Independent $\mathrm{T}$ test indicates statistical differences between metal contents of male and female crayfish $(* \mathrm{P}<0.05)$

Levels of $\mathrm{Cu}$ and $\mathrm{Zn}$ among experimental groups were not statistically different $(\mathrm{P}>0.05)$. But, considering the sexual status, there are statistically significant differences in metal levels in hemolymph among experimental groups $(\mathrm{P}<0.05)$, except $\mathrm{Cu}$ levels in male of freshwater crayfish. The lowest $\mathrm{Cu}$ and $\mathrm{Zn}$ levels were measured in females of control group. On the other hands, in males the lowest $\mathrm{Cu}$ and $\mathrm{Zn}$ levels were measured in Diet 1 . There were statistical differences in levels of $\mathrm{Cu}$ and $\mathrm{Zn}$ of both sexual status of freshwater crayfish among experimental groups $(\mathrm{P}<0.05)$.

Heavy metal concentrations in aquatic ecosystems are usually monitore by measuring their concentrations in water, sediments and biota ${ }^{15}$, which generally exist in low levels in water and attain considerable concentration in sediments and biota $^{16}$.

In a study on effects of dietary $\mathrm{Cu}$ on the Australian freshwater crayfish, Cherax destructor, Allinson et al. ${ }^{17}$ reported that high $\mathrm{Cu}$ concentrations were in gills, hemolymph and muscle. Similarly, certain levels of $\mathrm{Cu}$ were determined in hemolymph of A. leptodactylus in this study.

\section{Conclusion}

The results obtained in the present study, indicated that bioaccumulation of $\mathrm{Cu}$ in male freshwater crayfish $(A$. leptodactylus) was not significantly different among control and diet groups. In contrast, both $\mathrm{Zn}$ and $\mathrm{Cu}$ concentrations in hemolymph of female ones in diet groups were determined significantly higher than the control groups. Similarly MartínDíaz et $a l .{ }^{18}$ determined that metal accumulation differences 
were found between male and female crayfish, Procambarus clarkii. Further studies are needed to investigate the molecular effects of sex and its supplements on bioaccumulation of metals.

\section{ACKNOWLEDGEMENTS}

The authors would like to thank Prof. Dr. Durmus Boztug, for his help and support.

\section{REFERENCES}

1. M. Devi, D.A. Thomas, J.T. Barber and M. Fingerman, Ecotoxicol. Environ. Saf., 33, 38 (1996).

2. A.T. Khan, D.M. Forester and H.W. Mileke, Vet. Hum. Toxicol., 37, 426 (1995).

3. P.A. Schilderman, E.J. Moonen, L.M. Maas, I. Welle and J.C. Kleinjans, Ecotoxicol. Environ. Saf., 44, 241 (1999).

4. G. Bagatto and M.A. Alikhan, Bull. Environ. Contam. Toxicol., 38, 540 (1987).

5. D.J.H. Phillips and P.S. Rainbow, Biomonitoring of Trace Aquatic Contaminants: Ettore Majorana International Science Series, Chapman and Hall, London, p. 388 (1993).
6. D. Ni, L. Song, Q. Gao, L. Wu, Y. Yu, J. Zhao, L. Qiu, H. Zhang and F. Shi, Fish Shellfish Immunol., 23, 1032 (2007).

7. I. Mavelli, M.R. Ciriolo, L. Rossi, T. Meloni, G. Forteleoni, A. De Flora, U. Benatti, A. Morelli and G. Rotilio, Eur. J. Biochem., 139, 13 (1984).

8. A. Concetti, P. Massei, G. Rotilio, M. Brunori and E.A. Rachmilewitz, J. Lab. Clin. Med., 87, 1057 (1976).

9. G.W. Bryan, J. Mar. Biol. Assoc., 48, 303 (1968).

10. P.S. Rainbow and S.L. White, Hydrobiologia, 174, 245 (1989).

11. P.S. Rainbow, Estuar. Coast. Shelf. Sci., 21, 669 (1985).

12. U. Guner, Turk. J. Biol., 34, 405 (2010).

13. J.F. Bruno, J.D. Fridley, K.D. Bromberg and M.D. Bertness, in eds.: D.F. Sax, J.C. Stachowicz and S.D. Gaines, Species Invasions: Insights into Ecology, Evolution and Biogeography, Sinauer Associates Inc., Sunderland, Massachusetts, USA, p. 495 (2005).

14. AOAC, AOAC Official method 999. Association of Official Analytical Chemists. Arlington, VA, Ch. 9, pp. 16-19 (2000).

15. M. Camusso, L. Vigano and R. Ecotox, Environ. Safe., 31, 133 (1995).

16. H.N. Namminga and J. Wilhm, Proc. Oklahoma Acad. Sci., 56, 133 (1976).

17. G. Allinson, N.L. Laurenso, G. Pistone, F. Stagnitti and P. Jones, Ecotoxicol. Environ. Safe., 46, 117 (2000).

18. M.L. Martín-Díaz, S.R. Tuberty, C.L. McKenney Jr., J. Blasco, C. Sarasquete and T.A. Delvalls, Environ. Monit. Assess., 116, 169 (2006). 